\title{
ANALISA CONSUMERS ONLINE TOURISM CONFUSION PADA KONSUMEN LAKI-LAKI DAN PEREMPUAN PRODUK PARIWISATA
}

\author{
Oleh
}

\author{
Gede Bayu Rahanatha ${ }^{1}$ \\ Ni Nyoman Rsi Respati ${ }^{2}$ \\ Martina Carissa Dewi ${ }^{3}$ \\ Sarah Yulinar Adiputri ${ }^{4}$ \\ ${ }^{1,2}$ Fakultas Ekonomi dan Bisnis Universitas Udayana (Unud), Bali, Indonesia \\ bayurahanatha@yahoo.com
}

\begin{abstract}
ABSTRAK
Penelitian ini menganalisa model Consumers Online Tourism Confusion dikaji dari sisi konsumen laki-laki dan perempuan. Pencarian beda tingkat kebingungan di kalangan konsumen laki-laki dan perempuan akan bermanfaat bagi para pelaku usaha khususnya dalam hal strategi komunikasi pemasaran dan bagi dunia pendidikan, kajian ini akan memberikan wawasan terbaru mengenai proses penerimaan komunikasi secara online konsumen laki-laki dan perempuan. Untuk mencapai tujuan tersebut, penelitian ini akan dilakukan dengan pendekatan kuantitatif, dimana akan dilihat nilai perbedaan antara konsumen laki-laki dan perempuan dimana variabel-variabel bebas yang digunakan pada penelitian ini adalah: orientasi pembelanjaran, kesadaran akan harga dan kebutuhan akan kognisi, dengan variable terikat: kebingungan konsumen yang terjadi pada saat melakukan pencarian informasi di media internet. Populasi yang dalam penelitian ini adalah: Warga Negara Indonesia yang telah berusia minimal 18 tahun, menggunakan media online (internet) dalam mencari informasi produk pariwisata dan sedang merencakan perjalanan (liburan).Tujuan penelitian ini adalah untuk melihat pengaruh orientasi pembelajaran, kesadaran akan harga dan kebutuhan akan kognisi terhadap tingkat kebingungan konsumen dalam mencari informasi produk pariwisata. Konsumen yang menjadi subyek penelitian adalah Warga Negara Indonesia di wilayah Badung, Bali yang sedang merencakan liburan yang menggunakan akses internet sebagai sarana pencarian informasi produk pariwisata. Adapun hasil yang didapatkan adalah: orientasi pembelajaran berpengaruh negative dan signifikan terhadap kebingungan konsumen laki-laki. Kesadaran harga tidak berpengaruh signifikan terhadap kebingungan konsumen laki-laki, tingkat kebutuhan kognisi tidak berpengaruh signifikan terhadap kebingungan konsumen laki-laki, orientasi pembelajaran berpengaruh negative dan signifikan terhadap kebingungan konsumen perempuan, kesadaran harga tidak berpengaruh signifikan terhadap kebingungan konsumen perempuan, tingkat kebutuhan kognisi berpengaruh positif dan signifikan terhadap kebingungan konsumen perempuan.
\end{abstract}

Kata kunci: Komunikasi Pemasaran, Pariwisata, Online, Consumer ,Confussion. 


\section{Pendahuluan}

Kegiatan wisata dapat dikatakan sebagai perjalanan yang dilakukan oleh seseorang yang berada diluar wilayah tempat tinggalnya pada suatu periode tertentu dengan tujuan berlibur, mengunjungi keluarga maupun kerabat, perjalanan bisnis, dan tujuan lainnya (Assaker 2010). Meningkatnya akivitas perjalanan dewasa ini, telah mengukuhkan pariwisata sebagai suatu industri yang dapat dijadikan sebagai penopang perekonomian suatu Negara. Assaker (2010) menyatakan bahwa kedepannya, pariwisata akan menjadi industri yang berkembang sangat pesat, dan mampu menyumbangkan lapangan pekerjaan dengan jumlah yang sangat besar kedepannya. Kecenderungan ini, dilihat oleh para pebisnis yang berusaha untuk memaksimalkan laba perusahaan. Ekspansi yang dilakukan oleh para pelaku usaha, tidak hanya sekedar membangun bisnis baru, tetapi juga berlomba-lomba untuk meningkatkan citra merek perusahaan. Upaya yang dilakukan oleh perusahaan dalam hal peningkatan citra merek adalah komunikasi yang bersifat ekspansif, dimana hal ini didukung oleh perkembangan teknologi dewasa ini.

Perkembangan teknologi ini menurut Xiang dan Gretzel (2010) memang membuat konsumen memiliki kecenderungan untuk mendapatkan informasi yang mereka butuhkan secara online. Buhalis dan Law (2008) menyatakan bahwa adanya kecenderungan penggunaan media online pada konsumen dalam pencarian informasi, yang berakibat pada berubahnya pola berbelanja dan pola perencanaan liburan konsumen itu sendiri.

Besarnya jumlah informasi yang dapat diakses secara online membuat konsumen memiliki tuntutan yang lebih besar pada setiap bisnis yang dijalankan pelaku usaha. Konsumen tidak hanya menuntut kebutuhan yang memang benar-benar harus dipenuhi produsen, tetapi juga menuntut seperangkat atribut yang dapat memenuhi keinginan dari konsumen tersebut. Sirakaya dan Woodside (2005) juga menyatakan bahwa munculnya tuntutan yang lebih besar dari konsumen terjadi karena akses informasi yang lebih banyak dilakukan oleh konsumen itu sendiri. Lebih lanjut Sirakaya dan Woodside (2005) menyatakan bahwa upaya untuk mengakses informasi secara maksimal yang dilakukan oleh konsumen terjadi dikarenakan oleh adanya resiko kerugian secara finansial yang mungkin terjadi sebagai akibat dari kesalahan dalam pemilihan produk industri pariwisata yang terdiri dari banyak pilihan dan dengan keunikan masing-masing. Hal ini mengakibatkan produsen semakin spesifik dalam rancang bisnisnya untuk meladeni konsumen berdasarkan karakteristik demografi khususnya gender.

Pada penelitian-penelitian sebelumnya telah ditemukan adanya kecenderungan terjadinya kebingungan konsumen pada saat akses informasi secara online sebelum melakukan tindakan pembelian. Kebingunan konsumen dalam berbelanja online produk telekomunikasi diungkapkan oleh Turnbull et all (2000), fashion (Cheary, 1997), dan pariwisata (Matzler dan Waiguny, 2005).

Kajian demografi dalam penelitian ini menggunakan variable orientasi pembelanjaran, kesadaran akan harga dan kebutuhan akan kognisi yang akan diuji pengaruhnya terhadap tingkat kebingungan yang dialami konsumen produk pariwisata dalam melakukan tindakan pasca pengumpulan informasi ( $\mathrm{Lu}$ et all, 2015). Penelitian ini akan mengkonfirmasi model Consumers Online Tourism Confusion pada konsumen laki-laki dan perempuan dalam produk pariwisata berkewarganegaraan Indonesia. Berdasarkan paparan diuraikan sebelumnya, maka ada beberapa permasalahan yang dapat dijabarkan sebagai berikut:

1) Bagaimanakah pengaruh orientasi pembelanjaran terhadap kebingungan konsumen laki-laki dalam berbelanja produk pariwisata?

2) Bagaimanakah pengaruh kesadaran akan akan harga terhadap kebingungan konsumen laki-laki dalam berbelanja produk pariwisata? 
3) Bagaimanakah pengaruh kebutuhan akan kognisi terhadap kebingungan konsumen laki-laki dalam berbelanja produk pariwisata?

4) Bagaimanakah pengaruh orientasi pembelanjaran terhadap kebingungan konsumen perempuan dalam berbelanja produk pariwisata?

5) Bagaimanakah pengaruh kesadaran akan akan harga terhadap kebingungan konsumen perempuan dalam berbelanja produk pariwisata?

6) Bagaimanakah pengaruh kebutuhan akan kognisi terhadap kebingungan konsumen perempuan dalam berbelanja produk pariwisata?

\section{Kajian Pustaka}

Sub bab Kajian pustaka membahas variabel-variabel yang akan diuji pada penelitian ini yaitu: orientasi pembelanjaran, kesadaran akan harga, kebutuhan akan kognisi, dan kebingungan konsumen dan juga demografi.

\section{Demografi dan media online pada integrated marketing communication}

Belch dan Belch (2003) menyatakan bahwa komunikasi pemasaran terpadu adalah upaya terintegrasi yang dilakukan oleh perusahaan dalam rangka mencapai tujuan komunikasi itu sendiri. Upaya yang dilakukan harus memberdayakan keseluruhan alat komunikasi pemasaran yang memiliki keterkaitan satu sama lain. Periklanan tidak lagi berdiri sendiri, tetapi disandingkan dengan baruran promosi lainnya dengan memanfaatkan media yang tersedia.

Strategi yang dibuat oleh para pemasar hendaknya sesuai dengan karakteristik target pasar dan target reponden yang disasar. Adapun dari sisi demografi, para pemasar dapat memilah responden maupun target pasar berdasarkan:

1) Umur

2) Jenis Kelamin

3) Ukuran keluarga

4) Tingkat pendidikan

5) Pendapatan

6) Kelas social

Penentuan target pasar secara spesifik harus dilakukan agar pemasar dapat memilih media komunikasi komunikasi pemasaran yang akan dipergunakan.

Media online memiliki popularitas yang cukup besar dewasa ini. Buhalis (1998) menyatakan bahwa perubahan pola perilaku konsumen produk pariwisata sangat dipengaruhi perkembangan teknologi informasi. Penelitian selanjutnya yang dilakukan oleh Buhalis dan Law (2008) bahkan menyatakan bahwa internet telah merubah pola berbelanja konsumen produk pariwisata. Web 2.0 telah benar-benar mengubah pola pencarian informasi. Sosial Media yang muncul sebagai akibat dari moderinasi kehidupan social masyarakat telah membawa masyarakat pada tingkat ketergantungan tertentu pada media online, dimana hal ini tentu berimbas pada kebijakan komunikasi pemasaran perusahaan.

\section{Consumer online tourism confusion model}

Kecenderungan penggunaan media online yang dilakukan konsumen pada industri pariwisata ditengarai mampu menimbulkan kebingungan dikalangan konsumen itu sendiri. Turnbull et al. (2000) mendefinisikan kebingungan konsumen sebagai "kegagalan dari konsumen untuk menginteprestasikan secara tepat dari berbagai aspek produk / layanan, pada tahap pengolahan informasi dari sebuah proses komunikasi. Mitchell dan Papavassiliou 
(1999) mengemukakan bahwa pada tingkat tertentu, kebingungan yang terjadi pada konsumen saat mengakses informasi secara dapat mengakibatkan:

1) Konsumen mengalami kesulitan yang cukup tinggi dalam hal pembuatan keputusan akhir. Hal ini dikarenakan oleh keterpaparan informasi yang terlalu besar dimana pilihan produk atau jasa yang tersedia berjumlah sangat besar.

2) Terjadinya pengambilan keputusan secara tidak optimal pada konsumen ketika harus melakukan tindakan pembelian. Tidak optimal yang dimaksudkan disini adalah adanya perubahan keinginan dan kebutuhan dari rencana semula.

3) Pada tahapan komunikasi lebih lanjut, konsumen justru dapat memberikan negative words of mouth dikarenakan oleh kebingungannya.

Mitchell dan Papavassiliou (1999) serta Walsh dan Hennig (2002) selanjutnya merangkum kebingungan yang dialami oleh konsumen secara umum terdiri dari:

1) Ambiguity confusion, adalah suatu kebingungan konsumen yang diakibatkan oleh ketidaksesuaian pemahaman konsumen dari informasi yang didapatkan yang menyebabkan konsumen tidak meyakini rencana pembelian (Mitchell et all, 2004).

2) Overload confusion, suatu kondisi kebingungan konsumen dimana seorang individu mengalami dari keterpaparan informasi secara berlebihan yang mengakibatkan individu tersebut mengalami kesulitan di dalam memahami informasi yang diterima secara akurat (Mitchell et all, 2004).

3) Similarity confusion, adalah kondisi kebingungan konsumen diakibatkan oleh adanya informasi yang memiliki kemiripan antara satu merek dengan merek lainnya yang menyebabkan konsumen sulit untuk membedakan antara yang satu dengan yang lain (Mitchell et all, 2004). Similarity confusion didorong oleh adanya kemiripan antara satu merek dengan merek lain dari segi fungsi, atribut, kualitas (Walsh dan Hennig, 2002). Hal ini disebabkan oleh terjadinya persaingan yang ketat diantara para merek sehingga mereka menggunakan pendekatan yang serupa (Kent dan Allen, 1994; Poiesz dan Verhallen, 1989).

Menurut Mitchell dan Papavassiliou (1997), adapun tindak lanjut konsumen ketika mengalami kebingungan adalah sebagai berikut:

1) Tidak melakukan apa apa dan mengabaikan kebingungan

2) Menunda pembelian

3) Membatalkan pembelian

4) Melimpahkan keputusan pembelian ke pihak lain

5) Meninjau kembali tujuan pembelian

6) Mencari informasi tambahan

7) Menyusutkan alternatif produk yang akan dibeli

Konsep consumer online tourism confusion (COTC) dirangkai menjadi sebuah model oleh Lu dan Dogan pada tahun 2015. Motivasi dan kemampuan dari penerima pesan, pada model COTC ditentukan oleh lima karakteristik dari penerima pesan, diantaranya:

1) Pengalaman dalam menggunakan internet. (Frias et all, 2008) menyatakan bahwa pengalaman dalam berinternet adalah sebuah variable yang dijelaskan dengan kemamampuan seseorang untuk memproses informasi secara online. Sejumlah penelitian telah menunjukkan bahwa konsumen dengan pengalaman Internet yang cukup merasa lebih nyaman menggunakan channel online sementara yang lain mungkin enggan untuk menggunakan saluran online karena ketidakpastian yang dirasakan dan risiko (Montoya et all. 2003; Murray dan Schlacter. 1990).

2) Orientasi pembelanjaran. Individu yang memiliki orientasi belajar yang kuat berusaha untuk memahami hal-hal baru dan meningkatkan kemampuan dalam aktivitas tertentu (Deshon dan Gillespie, 2005). Ketika dihadapkan dengan situasi yang menantang, mereka 
yang memiliki orientasi belajar yang kuat akan merespon dengan perilaku adaptif dan akan menunjukkan kegigihan dalam menghadapi kesulitan, mendorong pencarian solusi baru, dan menunjukkan kinerja yang meningkat (Derue dan Wellman, 2009). Selain itu, ketika dihadapkan dengan situasi yang menantang, individu dengan orientasi belajar yang kuat akan melihat kesalahan sebagai umpan balik yang bermanfaat dan kesempatan untuk belajar dan dengan demikian sering meningkatkan upaya mereka untuk mengembangkan keterampilan dan pengetahuan baru (Gong, et all, 2009). Ciri kepribadian ini sangat terkait dengan motivasi individu untuk memproses dan memahami informasi yang diterima (Lu dan Dogan 2015)

3) Toleransi pada ambiguitas. Toleransi ambiguitas mengacu pada cara individu (atau kelompok) memandang dan memproses informasi yang bersifat ambigu pada saat mereka dihadapkan dengan situasi asing, kompleks (Furnham, 1994). Situasi ambigu yang dimaksud termasuk situasi yang sama sekali baru, situasi rumit di mana ada sejumlah besar symbol yang membutuhkan pemahaman, atau kondisi yang kontradiktif (Gurel, Altinay, \& Daniele, 2010). Konsumen akan melalui keadaan ambiguitas ketika konsumen mencoba untuk memahami lebih lanjut kondisi lingkungan yang dihadapi termasuk informasi yang dterima sebelum melakukan kegiatan pembelian (Walsh \& Yamin, 2005). Oleh karena itu, konsumen dengan tingkat toleransi ambiguitas rendah, dibandingkan dengan yang memiliki toleransi ambiguitas tinggi, cenderung menghabiskan lebih banyak waktu dan upaya untuk mengumpulkan, mengolah, dan memahami semua informasi yang tersedia dalam rangka untuk mengurangi kesempatan menjadi bingung.

4) Kesadaran akan harga. (Lichtenstein et al. 1993) mendefinisikan harga kesadaran sebagai sejauh mana konsumen memfokuskan secara eksklusif pada membayar harga yang rendah. Sementara (Jin et all. 2012) menyatakan bahwa konsumen dengan tingkat kesadaran harga yang tinggi akan selalu mencari penawaran dengan kesesuaian harga yang terbaik sehingga mereka cenderung memiliki kriteria pembelian yang jelas dan pendekatan mereka untuk berbelanja bersifat sistematis, menyeluruh dan efisien. (Lu dan Dogan, 2015) menyatakan harga untuk produk pariwisata atau jasa tertentu dapat bervariasi secara signifikan dari satu situs ke yang lain. Dengan keinginan untuk membayar harga yang rendah untuk produk dan jasa pariwisata, seorang individu harus memiliki motivasi tinggi untuk mengumpulkan dan memproses semua informasi online tersedia, serta membuat beberapa perbandingan dari sumber informasi yang berbeda.

5) Tingkat kebutuhan akan kognisi. Konsep kebutuhan kognisi pertama kali diperkenalkan oleh Cohen, Stotland dan Wolfe (1955) yang menyatakan bahwa kebutuhan akan kognisi adalah suatu kebutuhan untuk menstrukrur dan mengintegrasi situasi yang terjadi untuk mendapatkan sebuah kejelasan dari situasi tersebut. Menurut ( Lu dan Dogan 2015), tipe konsumen yang memiliki tingkat kebutuhan akan kognisi yang tinggi memiliki kecenderungan yang rendah terhadap kebingungan di dalam pencarian informasi secara online. 
Gede Bayu Rahanatha, Ni Nyoman Rsi Respati, Martina Carissa Dewi, dan Sarah Yulinar Adiputri. Analisa Consumer...

\section{Conceptual Model}

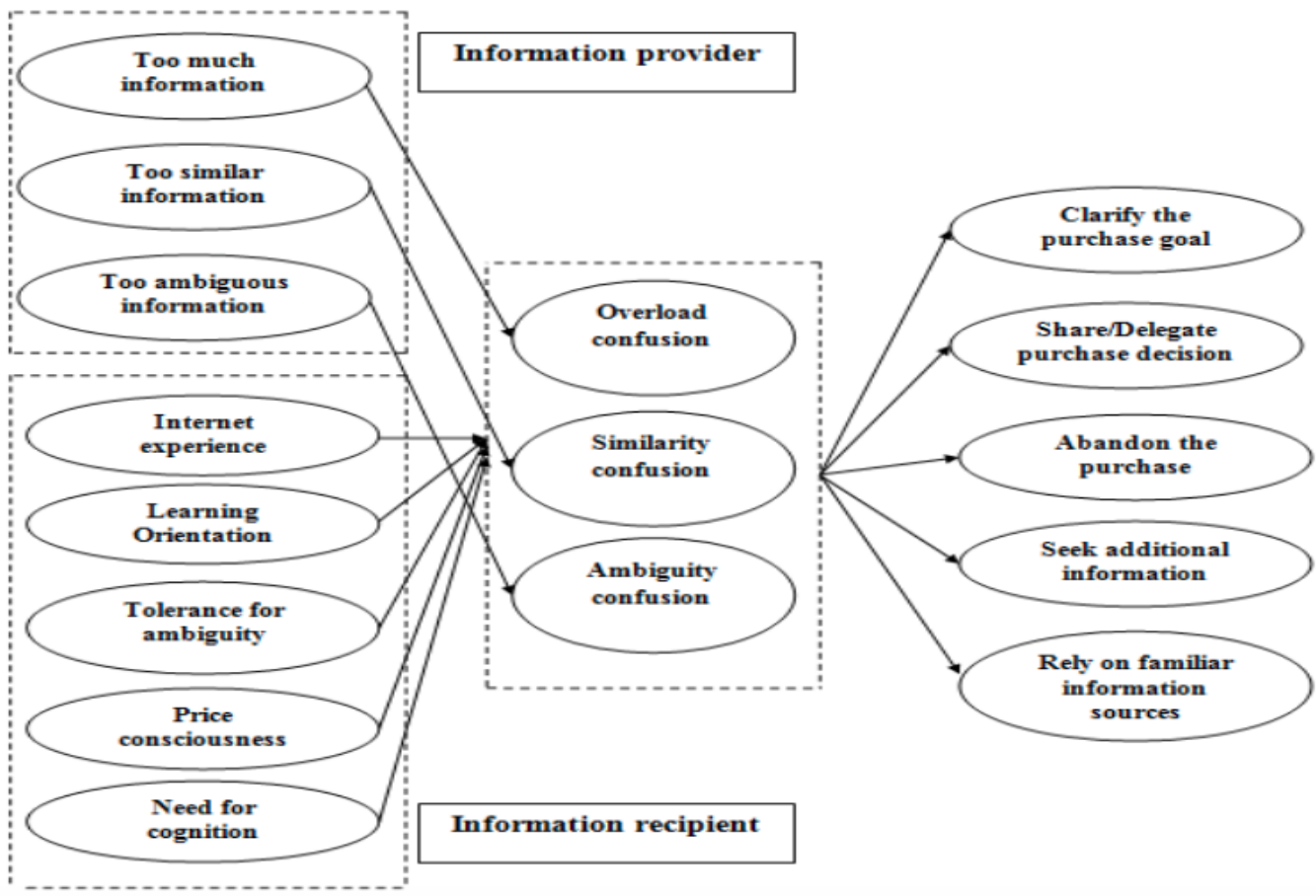

Gambar Consumer Online Tourism Confusion Model

\section{Kerangka Konsep Penelitian}

Teori consumer online tourism confusion menjadi dasar dalam pembuatan model penelitian ini. Adapun factor penyebab tingkat kebingungan yang diangkat dalam penelitian ini adalah orientasi pembelajaran, kesadaran akan harga dan kebutuhan akan kognisi. Dimana pada penelitian ini, keterkaitan antara varibel tersebut akan dilihat pada responden laki-laki dan perempuan secara terpisah. Kerangka konseptual dapat dilihat pada Gambar.

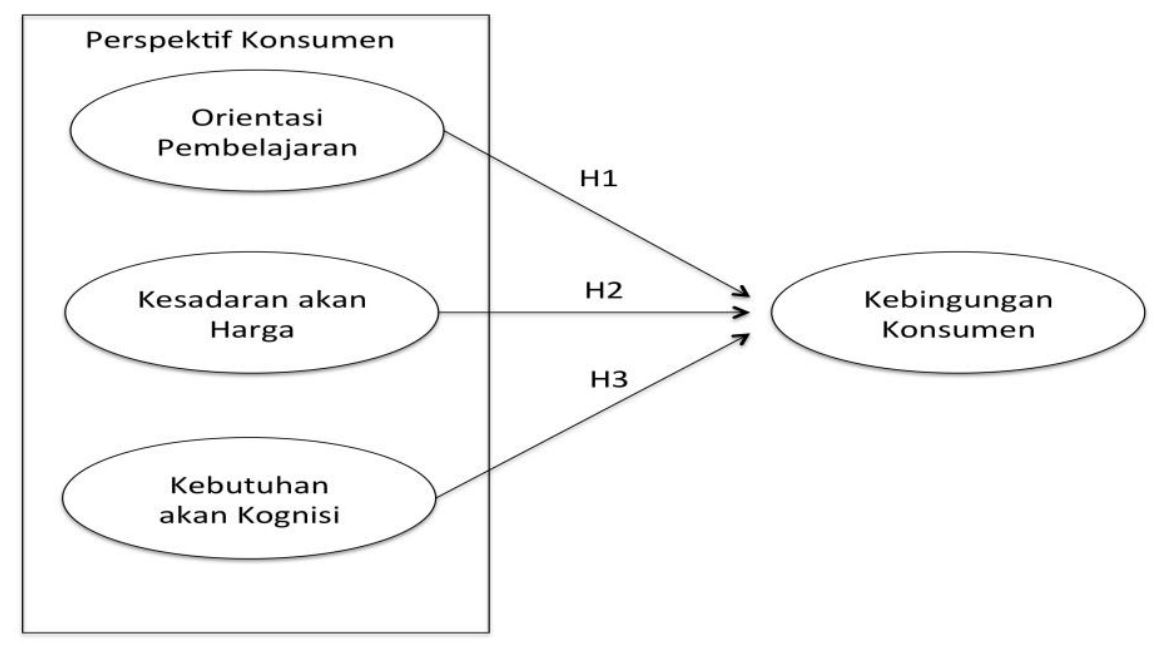

Gambar

Kerangka Konsep Penelitian 


\section{Hipotesis Penelitian:}

Berdasarkan kerangka konsep yang ada maka hipotesis penelitian yang dapat disusun adalah sebagai berikut.

Pengaruh orientasi pembelanjaran (X1) terhadap kebingungan konsumen laki-laki (Y)

Kajian sebelumnya menemukan bahwa semakin tinggi tingkat orientasi pembelanjaran seseorang, maka kecenderungan kebingungan yang akan dialami akan semakin rendah. Hal ini diungkapkan oleh DeShon dan Gillespie (2005) serta DeRue and Wellman (2009). Hasil yang berbeda ditemukan oleh Lu dan Dogan (2015) bahwa semakin tinggi tingkat orientasi pembelajaran, maka tingkat kebingungan akan semakin tinggi. Berdasarkan kajian empiris sebelumnya, maka dapat disusun hipotesis sebagai berikut.

H1 : Orientasi pembelanjaran (X1) berpengaruh negatif dan signifikan terhadap kebingungan konsumen laki-laki (Y)

\section{Pengaruh kesadaran akan harga (X2) terhadap kebingungan konsumen laki-laki (Y)}

Lu et all (2015) menemukan bahwa semakin tinggi tingkat kesadaran akan harga, maka tingkat kebingungan yang akan dialami akan semakin rendah. Salah satu factor yang ditengarai sebagai akibat dari hubungan negative dua variable tersebut adalah adanya kesediaan konsumen yang memiliki kesadaran harga tinggi untuk meluangkan tenaga dan waktu yang lebih banyak untuk mencari harga yang lebih murah. Penelitian ini senada dengan penelitian dari Grewal dan Marmorstein (1994) serta Konucs et all, (2008) Berdasarkan kajian empiris sebelumnya, maka dapat disusun hipotesis sebagai berikut.

H2 : Kesadaran akan harga (2) berpengaruh negatif dan signifikan terhadap kebingungan konsumen laki laki.

\section{Pengaruh kebutuhan akan kognisi (X3) terhadap kebingungan konsumen laki-laki (Y)}

Kebutuhan akan kognisi adalah kondisi psikologi seseorang yang membutuhkan kejelasan dari suatu fenomena. Kebutuhan akan kognisi yang tinggi ditandai dengan adanya kemauan untuk menghadapi situasi yang bersifat kompleks. Hal ini diungkapkan oleh: Cohen, Stotland dan Wolfe (1955) serta Cacioppo and Petty (1982). Lebih lanjut dinyatakan bahwa semakin tinggi tingkat kebutuhan akan kognisi, maka pihak-pihak tersebut akan semakin mudah untuk mengatasi masalah yang rumit dan terhindar dari kebingungan. Penelitian tersebut bertentangan dengan hasil dari penelitian Lu dan Dogan (2015) yang menyatakan bahwa sebaliknya, bahwa semakin tinggi tingkat kognisi, maka tingkat kebingungan pun akan semakin meningkat. Berdasarkan kajian empiris sebelumnya, maka dapat disusun hipotesis sebagai berikut:

H3 : Kebutuhan akan kognisi (X3) berpengaruh positif dan signifikan terhadap kebingungan konsumen laki-laki (Y)

Pengaruh orientasi pembelanjaran (X1) terhadap kebingungan konsumen perempuan (Y)

Kajian sebelumnya menemukan bahwa semakin tinggi tingkat orientasi pembelanjaran seseorang, maka kecenderungan kebingungan yang akan dialami akan semakin rendah. Hal ini diungkapkan oleh DeShon dan Gillespie (2005) serta DeRue and Wellman (2009). Hasil yang berbeda ditemukan oleh Lu dan Dogan (2015) bahwa semakin tinggi tingkat orientasi pembelajaran, maka tingkat kebingungan akan semakin tinggi. Berdasarkan kajian empiris sebelumnya, maka dapat disusun hipotesis sebagai berikut. 
H1 : Orientasi pembelanjaran (X1) berpengaruh negatif dan signifikan terhadap kebingungan konsumen perempuan (Y)

\section{Pengaruh kesadaran akan harga (X2) terhadap kebingungan konsumen perempuan (Y)}

Lu et all (2015) menemukan bahwa semakin tinggi tingkat kesadaran akan harga, maka tingkat kebingungan yang akan dialami akan semakin rendah. Salah satu factor yang ditengarai sebagai akibat dari hubungan negative dua variable tersebut adalah adanya kesediaan konsumen yang memiliki kesadaran harga tinggi untuk meluangkan tenaga dan waktu yang lebih banyak untuk mencari harga yang lebih murah. Penelitian ini senada dengan penelitian dari Grewal dan Marmorstein (1994) serta Konucs et all, (2008) Berdasarkan kajian empiris sebelumnya, maka dapat disusun hipotesis sebagai berikut.

H2 : Kesadaran akan harga (2) berpengaruh negatif dan signifikan terhadap kebingungan konsumen perempuan.

\section{Pengaruh kebutuhan akan kognisi (X3) terhadap kebingungan konsumen perempuan} (Y)

Kebutuhan akan kognisi adalah kondisi psikologi seseorang yang membutuhkan kejelasan dari suatu fenomena. Kebutuhan akan kognisi yang tinggi ditandai dengan adanya kemauan untuk menghadapi situasi yang bersifat kompleks. Hal ini diungkapkan oleh: Cohen, Stotland dan Wolfe (1955) serta Cacioppo and Petty (1982). Lebih lanjut dinyatakan bahwa semakin tinggi tingkat kebutuhan akan kognisi, maka pihak-pihak tersebut akan semakin mudah untuk mengatasi masalah yang rumit dan terhindar dari kebingungan. Penelitian tersebut bertentangan dengan hasil dari penelitian Lu dan Dogan (2015) yang menyatakan bahwa sebaliknya, bahwa semakin tinggi tingkat kognisi, maka tingkat kebingungan pun akan semakin meningkat. Berdasarkan kajian empiris sebelumnya, maka dapat disusun hipotesis sebagai berikut:

H3 : Kebutuhan akan kognisi (X3) berpengaruh positif dan signifikan terhadap kebingungan konsumen perempuan (Y)

\section{Metodologi Penelitian}

Penelitian ini menggunakan pendekatan kuantitatif dimana variable bebas: orientasi pembelajaran, kesadaran akan harga dan tingkat kebutuhan akan kognisi akan dilihat pengaruhnya terhadap tingkat kebingungan konsumen. Pada penelitian ini akan mengkonfirmasi model yang dipergunakan pada kelompok sampel laki-laki dan perempuan.

\section{Lokasi Penelitian}

Penelitian ini akan dilakukan di wilayah Badung, Provinsi Bali dimana penyebaran kuesioner dilakukan secara offline dan online kepada masyarakat Indonesia yang yang berdomisili di Badung Bali. Pemilihan wilayah Badung Bali dikarenakan memiliki tingkat pemasukan dengan rata-rata tertinggi di Bali (UMR Kabupaten tertinggi di Bali) dan memiliki kecenderungan aktivitas berwisata yang tinggi. 


\section{Populasi dan Sample}

Penentuan populasi penelitian dilakukan dengan teknik purposif. Kriteria populasi yang digunakan dalam penelitian ini adalah:

1) Warga Negara Indonesia yang telah berusia minimal 17 tahun

2) Menggunakan media online (internet) dalam mencari informasi produk pariwisata

3) Sedang merencakan perjalanan (kegiatan berwisata)

Jumlah sampel yang akan digunakan dalam penelitian ini adalah sebanyak 150 orang. Pengambilan sampel ini akan dilakukan secara purposif melalui media internet dan visitasi ke lokasi-lokasi pusat keramaian di Bali agar dapat disesuaikan dengan kriteria populasi yang telah ditetapkan.

\section{Teknik Pengukuran Variabel}

Skala pengukuran yang dipergunakan dalam penelitian ini menggunakan skala Likert lima tingkat, yaitu dari sangat tidak setuju $=1$, tidak setuju $=2$, cukup setuju $=3$, setuju $=4$, dan sangat setuju $=$ 5.

\section{Jenis Data}

Berdasarkan sumbernya data dapat dibedakan menjadi data primer dan sekunder. Data primer adalah data yang dikumpulkan secara khusus untuk melaksanakan proyek penelitian yang dilakukan. Data sekunder adalah data yang sudah dikumpulkan oleh pihak tertentu untuk tujuan lain (Saunders, 2016). Penelitian ini menggunakan data sekunder yang mendukung pembahasan penelitian.

\section{Teknik Pengumpulan Data}

Pengumpulan data pada penelitian ini dilakukan dengan cara penyebaran kuesioner yang dilakukan melalui e-mail dan visitasi ke pusat keramaian di Badung, Bali.

\section{Uji Instrumen Penelitian}

Alat yang dipergunakan untuk melakukan pengukuran variabel yang diuji pada penelitian disebut dengan instrumen penelitian. Bentuk instrumen penelitian yang digunakan adalah daftar pertanyaan atau kuesioner karena sifat penelitian ini adalahpenelitian survey yang memerlukan data primer. Indikator dari instrument penelitian ini diambil dari pengukuran yang sudah pernah dilakukan sebelumnya. Berikut adalah instrumen yang digunakan pada penelitian ini:

1) Orientasi Pembelajaran (X1)

Individu yang memiliki orientasi belajar yang kuat berusaha untuk memahami hal-hal baru dan meningkatkan tingkat kemampuan dalam aktivitas tertentu (Deshon dan Gillespie, 2005). Ciri kepribadian ini sangat terkait dengan motivasi individu untuk memproses dan memahami informasi yang diterima ( $\mathrm{Lu}$ et al., 2015). Adapun indikator yang dipergunakan untuk mengukur konstruk orientasi pembelajaran ( Lu et al., 2015) adalah:

a. Apabila gagal menyelesaikan sebuah tugas, responden akan berusaha lebih keras lagi apabila dihadapkan dengan tugas yang sama ke depannya. 
b. Responden lebih memilih untuk mengerjakan tugas-tugas yang memaksa untuk mempelajari hal-hal yang baru.

c. Kesempatan untuk mempelajari hal-hal baru yang penting bagi responden.

d. Kesempatan untuk menambah kemampuan (skill) penting bagi responden.

e. Ketika mengalami kesulitan memecahkan masalah, responden mencoba mengatasinya dengan pendekatan yang berbeda.

2) Kesadaran akan Harga (X2)

Lichtenstein et al. (1993) mendefinisikan kesadaran akan harga sebagai "sejauh mana konsumen memfokuskan secara eksklusif pada membayar harga yang rendah. Lu et al. (2015) menyatakan harga untuk produk pariwisata atau jasa tertentu dapat bervariasi secara signifikan dari satu situs ke situs lainnya. Dengan keinginan untuk membayar harga yang rendah untuk produk dan jasa pariwisata, seorang individu harus memiliki motivasi tinggi untuk mengumpulkan dan memproses semua informasi online tersedia, serta membuat beberapa perbandingan dari sumber informasi yang berbeda. Adapun indikator yang dipergunakan untuk mengukur konstruk kesadaran akan harga ( Lu et al., 2015) adalah:

a. Adanya kerelaan berpindah dari satu toko ke toko lainnya untuk mendapatkan barang yang responden inginkan dengan harga yang lebih murah.

b. Kelebihan uang yang didapatkan responden dari hasil berburu suatu barang dengan harga lebih murah dirasa sepadan dengan waktu yang dihabiskan.

c. Kelebihan uang yang didapatkan responden dari hasil berburu suatu barang dengan harga lebih murah dirasa sepadan dengan tenaga yang dihabiskan.

3) Tingkat Kebutuhan akan Kognisi (X3)

Cohen et al. (1955) yang menyatakan bahwa kebutuhan akan kognisi adalah suatu kebutuhan untuk menstruktur dan mengintegrasi situasi yang terjadi demi mendapatkan sebuah kejelasan dari situasi tersebut. Menurut $\mathrm{Lu}$ et al. (2015), tipe konsumen yang memiliki tingkat kebutuhan akan kognisi yang tinggi memiliki kecenderungan yang rendah terhadap kebingungan di dalam pencarian informasi secara online. Adapun indikator yang dipergunakan untuk mengukur konstruk kebutuhan akan kognisi ( Lu et al., 2015) adalah:

a. Responden lebih menyukai memikirkan hal yang kompleks dibandingkan dengan hal yang bersifat sederhana.

b. Rasa senang yang dialami responden ketika diberikan tanggung jawab atas hal-hal yang membutuhkan banyak pemikiran.

c. Kecenderungan responden yang lebih menyukai kehidupan yang kompleks dibandingkan dengan hidup yang terlalu mudah ditebak.

4) Kebingungan Konsumen (Y1)

Turnbull et al. (2000) mendefinisikan kebingungan konsumen sebagai "kegagalan dari konsumen untuk menginteprestasikan secara tepat dari berbagai aspek produk/layanan, pada tahap pengolahan informasi dari sebuah proses komunikasi. Adapun dimensi dan indikator yang dipergunakan untuk mengukur konstruk kebingungan konsumen ( Lu et al., 2015) adalah:

\section{Ambiguity confusion}

a. Responden merasa informasi yang didapatkan secara online tentang produk pariwisata tidak jelas.

b. Informasi tentang produk pariwisata yang didapatkan secara online justru membuat responden merasa bingung karena terlalu sering di-update. 
c. Responden merasa tidak mendapatkan informasi yang dibutuhkan secara online karena terlalu bias.

\section{Overload Confusion}

d. Adanya kebingungan pada diri responden ketika mencari informasi produk pariwisata dikarenakan jumlah website yang menjadi sumber pencarian informasi terlalu banyak.

e. Terjadinya kondisi semakin bingung pada diri responden ketika semakin banyak website produk pariwisata yang jelajahi.

f. Terjadinya kebingungan dengan banyaknya informasi tentang produk pariwisata yang didapatkan responden secara online.

\section{Similarity Confusion}

g. Terjadinya kebingungan pada diri responden untuk menemukan situs produk pariwisata (website) yang mampu memberikan informasi yang sesuai dengan kebutuhan.

h. Responden merasa antara satu website dengan yang lain memiliki kemiripan konten.

i. Responden merasa mustahil untuk membedakan isi antara website yang satu dengan yang lainnya. SPSS 17.0.

Data yang diperoleh dalam penelitian ini akan dianalisis dengan menggunakan alat bantu

\section{MetodeAnalisis Data}

\section{Uji Asumsi Klasik}

Penelitian ini menggunakan teknik analisis data berupa regresi berganda. Sebelumnya, akan dilakukan terlebih dahulu uji asumsi klasik yaitu sebuah uji atau analisis yang digunakan untuk menilai persyaratan-persyaratan yang harus dipenuhi oleh suatu data, yang nantinya akan dianalisis secara statistik khususnya untuk analisis linier berganda (Suyana, 2009:89). Adapun uji asumsi klasik yang dilakukan adalah sebagai berikut:

\section{Uji Normalitas}

Pada tahap uji normalitas, akan dilihat dalam residual dari model regresi yang dibuat berdistribusi normal ataukah tidak. Model regresi yang baik adalah memiliki distribusi residual yang normal atau mendekati normal (Suyana, 2009:89).

\section{Uji Multikolinearitas}

Uji multikolinieritas adalah adanya lebih dari satu hubungan linier yang sempurna. Dalam sebuah regresi berganda tidak boleh terjadi multikolinieritas karena apabila terjadi multikolinieritas apalagi kolinier sempurna maka regresi dari variabel bebas tidak dapat ditentukan. Pendeteksiannya dilakukan dengan menggunakan VIF (variance inflation factor). Jika nilai VIF-nya kurang dari 10 maka data tidak terdapat multikolinieritas

\section{Uji Heterokedastisitas}

Uji heterokedastisitas bertujuan untuk menguji apakah dalam model regresi terjadi ketidaksamaan varians dari residual satu pengamatan ke pengamatan yang lain (Suyana, 2009:94).

\section{Analisis Regresi Berganda}


Pada penelitian ini digunakan teknik analisis data berupa teknik analisis regresi linear berganda yaitu suatu analisis peramalan nilai pengaruh dua variabel bebas atau lebih terhadap variabel terikat untuk membuktikan ada atau tidaknya hubungan fungsi atau hubungan kausal antara dua variabel bebas atau lebih dengan satu variabel terikat menurut Riduwan (2011 : 108).

\section{Hasil dan Pembahasan}

Tabel

Distribusi Responden menurut Karakteristik Responden terhadap persepsi Kebingungan Konsumen

\begin{tabular}{|c|c|c|c|c|c|c|c|c|}
\hline \multirow[t]{2}{*}{ No. } & \multirow[t]{2}{*}{ Variabel } & \multirow[t]{2}{*}{ Klasifikasi } & \multicolumn{2}{|c|}{$\begin{array}{c}\text { Jumlah } \\
\text { Responden }\end{array}$} & \multicolumn{2}{|c|}{$\begin{array}{c}\text { Konsumen } \\
\text { Laki-laki }\end{array}$} & \multicolumn{2}{|c|}{$\begin{array}{l}\text { Konsumen } \\
\text { Perempuan }\end{array}$} \\
\hline & & & orang & $\%$ & orang & $\%$ & orang & $\%$ \\
\hline \multirow[t]{5}{*}{1.} & \multirow{5}{*}{$\begin{array}{l}\text { Usia } \\
\text { (Generasi) }\end{array}$} & $\leq 21$ tahun $(Z)$ & 77 & 51,4 & 36 & 51,4 & 41 & 51,3 \\
\hline & & $\begin{array}{c}\text { 22-34 tahun } \\
\text { (Y) }\end{array}$ & 54 & 36,0 & 28 & 40,0 & 26 & 32,5 \\
\hline & & $\begin{array}{l}35-50 \text { tahun } \\
(\mathrm{X})\end{array}$ & 17 & 11,3 & 4 & 5,7 & 13 & 16,2 \\
\hline & & $\begin{array}{c}\geq 51 \text { tahun } \\
\quad(\text { Baby } \\
\text { Boomer })\end{array}$ & 2 & 1,3 & 2 & 2,9 & - & - \\
\hline & & Total & 150 & 100 & 70 & 100 & 80 & 100 \\
\hline \multirow[t]{5}{*}{2.} & \multirow[t]{5}{*}{ Pendidikan } & SMA/SMK & 88 & 58,7 & 43 & 61,4 & 45 & 56,3 \\
\hline & & Diploma & 8 & 5,3 & 2 & 2,9 & 6 & 7,5 \\
\hline & & Sarjana & 45 & 30,0 & 21 & 30,0 & 24 & 30,0 \\
\hline & & Magister & 9 & 6,0 & 4 & 5,7 & 5 & 6,2 \\
\hline & & Total & 150 & 100,0 & 70 & 100,0 & 80 & 100,0 \\
\hline \multirow[t]{5}{*}{3.} & \multirow[t]{5}{*}{$\begin{array}{l}\text { Status } \\
\text { Pekerjaan }\end{array}$} & $\begin{array}{c}\text { Pelajar / } \\
\text { Mahasiswa }\end{array}$ & 85 & 56,7 & 39 & 55,7 & 46 & 57,5 \\
\hline & & $\begin{array}{c}\text { Pegawai } \\
\text { Negeri }\end{array}$ & 11 & 7,3 & 7 & 10,0 & 4 & 5,0 \\
\hline & & $\begin{array}{l}\text { Pegawai } \\
\text { Swasta }\end{array}$ & 39 & 26,0 & 20 & 28,6 & 19 & 23,8 \\
\hline & & Wiraswasta & 15 & 10,0 & 4 & 5,7 & 11 & 13,7 \\
\hline & & Total & 150 & 100,0 & 70 & 100,0 & 80 & 100,0 \\
\hline
\end{tabular}

Sumber : Lampiran 1

Generasi Z menjadi responden terbanyak dengan persentase sejumlah 51,4 \%dimana 51,4\% pada konsumen laki-laki dan $51,3 \%$ pada konsumen perempuan, hal ini dapat terjadi dikarenakan generasi $\mathrm{Z}$ sangat lekat dengan dunia digital. Pendidikan terakhir dari responden dengan persentase terbesar adalah SMA/SMK yaitu 58,7\% dimana $61,4 \%$ pada konsumen laki-laki dan 56,3\% pada konsumen perempuan. Responden dengan status pekerjaan pelajar / mahasiswa mendominasi dengan persentase sebesar 56,7 \% dimana 55,7\% pada konsumen laki-laki dan $57,5 \%$ pada konsumen perempuan, dan dari total 150 responden yang didapat pada penelitian ini terbagi atas 70 responden laki-laki astau sebesar 46,7\% dan 80 responden perempuan atau sebesar $53,3 \%$.

\section{Hasil Pengujian Instrumen Uji Validitas}

Validitas instrumen penelitian dinyatakan valid jika memiliki koefisien korelasi Pearson Product Moment (r) > 0,3 untuk masing - masing butir pernyataan. (Sugiyono, 2014:178). Adapun hasil uji validasi instrument dapat dilihat pada Tabel. 
Tabel

Hasil Uji Validitas Instrumen

\begin{tabular}{|c|c|c|c|}
\hline Variabel & Indikator & $\begin{array}{l}\text { Koefisien } \\
\text { Korelasi }\end{array}$ & Keterangan \\
\hline \multirow{5}{*}{$\begin{array}{l}\text { Orientasi } \\
\text { Pembelajaran } \\
\qquad \text { (X1) }\end{array}$} & $\mathrm{X} 1.1$ & 0,804 & Valid \\
\hline & $\mathrm{X} 1.2$ & 0,787 & Valid \\
\hline & $\mathrm{X} 1.3$ & 0,835 & Valid \\
\hline & $\mathrm{X} 1.4$ & 0,855 & Valid \\
\hline & X1.5 & 0,816 & Valid \\
\hline \multirow{3}{*}{$\begin{array}{l}\text { Kesadaran akan } \\
\text { Harga } \\
\qquad \text { (X2) }\end{array}$} & $\mathrm{X} 2.1$ & 0,915 & Valid \\
\hline & $\mathrm{X} 2.2$ & 0,915 & Valid \\
\hline & $\mathrm{X} 2.3$ & 0,897 & Valid \\
\hline \multirow{3}{*}{$\begin{array}{l}\text { Kebutuhan } \\
\text { akan Kognisi } \\
\text { (X3) }\end{array}$} & X3.1 & 0,919 & Valid \\
\hline & X3.2 & 0,868 & Valid \\
\hline & X3.3 & 0,916 & Valid \\
\hline \multirow{9}{*}{$\begin{array}{l}\text { Kebingungan } \\
\text { Konsumen } \\
\qquad(\mathbf{Y})\end{array}$} & $\mathrm{Y} 1.1$ & 0,801 & Valid \\
\hline & Y1.2 & 0,784 & Valid \\
\hline & $\mathrm{Y} 1.3$ & 0,856 & Valid \\
\hline & Y1.4 & 0,923 & Valid \\
\hline & Y1.5 & 0,930 & Valid \\
\hline & Y1.6 & 0.902 & Valid \\
\hline & Y1.7 & 0.921 & Valid \\
\hline & Y1.8 & 0,613 & Valid \\
\hline & Y1.9 & 0,687 & Valid \\
\hline
\end{tabular}

Sumber : Lampiran 2

Hasil uji validitas pada tabel menunjukkan bahwa seluruh variabel memiliki nilai koefisien dengan skor total seluruh item pernyataan lebih besar dari 0,30. Hal ini menunjukan bahwa butir - butir pernyataan dalam isntrumen penelitian adalah valid.

\section{Uji Reliabilitas}

Suatu intrumen dikatakan reliabel apabila instrument penelitian memiliki nilai Alpha Cronbach lebih dari 0,60. Adapun hasil uji reliabilitas dalam penelitian ini dapat ditunjukan pada Tabel berikut :

\section{Tabel}

\section{Hasil Uji Reliabilitas}

\begin{tabular}{|c|l|c|c|}
\hline No & \multicolumn{1}{|c|}{ Variabel } & $\begin{array}{c}\text { Cronbach's } \\
\text { Alpha }\end{array}$ & Keterangan \\
\hline 1. & Orientasi Pembelajaran $\left(\mathrm{X}_{1}\right)$ & 0,868 & Reliabel \\
\hline 2. & Kesadaran akan Harga $\left(\mathrm{X}_{2}\right)$ & 0,892 & Reliabel \\
\hline 3. & Kebutuhan akan Kognisi $\left(\mathrm{X}_{3}\right)$ & 0,881 & Reliabel \\
\hline 4. & Kebingungan Konsumen $(\mathrm{Y})$ & 0,943 & Reliabel \\
\hline
\end{tabular}

Sumber : Lampiran 3 
Tabel 5.7 menunjukan bahwa nilai Cronbach's Alpha untuk masing - masing variabel lebih besar dari 0,6. Hal ini menunjukkan bahwa semua instrumen penelitian reliabel sehingga dapat digunakan untuk melakukan penelitian.

\section{Uji Asumsi Klasik}

Hasil uji normalitas pada Tabel melalui analisis Kolmogorov-Smirnov menunjukan nilai Asymp. Sig. (2-tailed) pada konsumen laki-laki sebesar 0,710>0,05 dan pada konsumen perempuan sebesar 0,754 >0,05. Sehingga dapat disimpulkan bahwa data terdistribusi dengan normal.

Tabel

\section{Hasil Uji Normalitas}

\begin{tabular}{|l|l|r|r|}
\hline \multicolumn{2}{|c|}{} & $\begin{array}{c}\text { Unstandardized Residual } \\
\text { Konsumen Laki-Laki }\end{array}$ & $\begin{array}{c}\text { Unstandardized } \\
\text { Residual Konsumen } \\
\text { Perempuan }\end{array}$ \\
\hline $\mathrm{N}$ & Mean & 70 & 80 \\
\cline { 2 - 4 } $\begin{array}{l}\text { Normal } \\
\text { Parameters }\end{array}$ & Standard Deviation & 0 & 0 \\
\hline \multirow{3}{*}{$\begin{array}{l}\text { Most Extreme } \\
\text { Differences }\end{array}$} & Absolute & 0.84320363 & 0.73208494 \\
\cline { 2 - 4 } & Positive & 0.084 & 0.075 \\
\cline { 2 - 4 } & Negative & -0.084 & -0.076 \\
\hline \multicolumn{2}{|l|}{ Kolmogorov-Smirnov Z } & 0.701 & 0.674 \\
\hline \multicolumn{2}{|l|}{ Asymp. Sig. (2-tailed) } & 0.710 & 0.754 \\
\hline
\end{tabular}

Sumber: Lampiran 4

Uji multikolinearitas ditunjukkan pada Tabel dimana didapat bahwa nilai tolerance variabel bebas pada konsumen laki-laki sebesar 0,900 hingga 0,968 dan pada konsumen perempuan sebesar 0.969 hingga 0.984 dimana berada di atas 0,1 dan nilai VIF pada konsumen laki-laki sebesar 1,033 hingga 1,111 dan pada konsumen perempuan sebesar 1.016 hingga 1.032, dimana berada di bawah 10. Jadi dapat disimpulkan bahwa pada model tidak terdapat gejala multikolinearitas.

Tabel

Hasil Uji Multikolinearitas

\begin{tabular}{|l|c|c|c|c|}
\hline \multirow{2}{*}{ Variabel } & \multicolumn{2}{|c|}{ Konsumen Laki-Laki } & \multicolumn{2}{c|}{ Konsumen Perempuan } \\
\cline { 2 - 5 } & Tolerance & VIF & Tolerance & VIF \\
\hline Orientasi Pembelajaran & .968 & 1.033 & .984 & 1.016 \\
Kesadaran Harga & .900 & 1.111 & .969 & 1.032 \\
Tingkat Kebutuhan Kognisi & .929 & 1.077 & .975 & 1.026 \\
\hline
\end{tabular}

Sumber: Lampiran 4

Uji heteroskedastisitas ditunjukkan pada Tabel dengan uji glejser dimana didapat hasil bahwa tingkat signifikansi setiap variabel bebas pada responden laki-laki maupun 
perempuan di atas 0,05 . Sehingga dapat dikatakan bahwa model regresi tidak mengandung adanya heteroskedastisitas.

Tabel

Hasil Uji Heteroskedastisitas

\begin{tabular}{|l|c|c|}
\hline \multicolumn{1}{|c|}{ Variabel } & $\begin{array}{c}\text { Sig. Konsumen Laki- } \\
\text { laki }\end{array}$ & $\begin{array}{c}\text { Sig. Konsumen } \\
\text { Perempuan }\end{array}$ \\
\hline (Constant) & .750 & .449 \\
Orientasi Pembelajaran & .533 & .326 \\
Kesadaran Harga & .151 & .085 \\
Tingkat Kebutuhan Kognisi & .184 & .057 \\
\hline
\end{tabular}

Sumber: Lampiran 4

\section{Hasil Analisis Data}

\section{Hasil Analisis Regresi}

Analisis regressi dengan menggunakan program SPSS dilakukan dalam penelitian ini untuk menganalisis bagaimana pengaruh tiga variable bebas yaitu: orientasi pembelajaran, kesadaran harga dan tingkat kebutuhan kognisi terhadap variable kebingungan konsumen. Hasil analisis regresi linear berganda untuk pengujian hubungan antar variabel dalam penelitian ini secara lengkap dapat dilihat pada Tabel.

Tabel

Hasil Analisis Regresi Linear Berganda Konsumen Laki-Laki

\begin{tabular}{|c|c|c|c|c|c|}
\hline \multirow{2}{*}{ Model } & \multicolumn{2}{|c|}{ Unstandardized Coefficients } & \multirow{2}{*}{$\begin{array}{c}\begin{array}{c}\text { Standardized } \\
\text { Coefficients }\end{array} \\
\text { Beta }\end{array}$} & \multirow{2}{*}{$\mathrm{T}$} & \multirow{2}{*}{ Sig. } \\
\hline & $B$ & Std. Error & & & \\
\hline (Constant) & 5.551 & 0.951 & & 5.839 & 0.000 \\
\hline Orientasi Pembelajaran & -0.504 & 0.177 & -0.327 & -2.855 & 0.006 \\
\hline Kesadaran Harga & -0.160 & 0.116 & -0.164 & -1.380 & 0.172 \\
\hline Tingkat Kebutuhan & 0.073 & 0.128 & 0.067 & .572 & 0.569 \\
\hline \multicolumn{2}{|c|}{$\begin{array}{ll}\text { Kognis1 } & 1 \\
\text { R Square } & =0.163\end{array}$} & \multicolumn{4}{|c|}{ R Square $\quad=0,163$} \\
\hline Adjusted R Square $=0$ & \multirow{2}{*}{\multicolumn{5}{|c|}{$=0,125$}} \\
\hline $\mathrm{F}$ & \multicolumn{3}{|c|}{$=4.284$} & & \\
\hline Sig & \multicolumn{5}{|c|}{$=0,008$} \\
\hline
\end{tabular}

Sumber : Lampiran 4

Berdasarkan hasil analisis pada Tabel dapat disusun persamaan regresi linear sebagai berikut:

$Y=5.551-0,504 X_{1}-0,160 X_{2}+0,073 X_{3}+e$

Keterangan:

$\mathrm{Y}=$ Kebingungan Konsumen 
$\mathrm{X}_{1} \quad=$ Orientasi Pembelajaran

$\mathrm{X}_{2} \quad=$ Kesadaran Harga

$\mathrm{X}_{3} \quad=$ Tingkat Kebutuhan Kognisi

Nilai $\mathrm{R}^{2}$ sebesar 0,163 dari Tabel berarti bahwa model Consumers Online Tourism mempengaruhi kebingungan konsumen sebesar 16,3\% sedangkan sisanya sebesar 83,7 \% dipengaruhi oleh factor lain. Persamaan regresi yang didapat dari Tabel 5.8 dapat dijelaskan sebagai berikut. Koefisien regresi untuk orientasi pembelajaran pada konsumen laki-laki sebesar - 0,504 dengan Sig. t sebesar 0,006 mengindikasikan bahwa orientasi pembelajaran berpengaruh negative dan signifikan terhadap kebingungan konsumen. Koefisien kesadaran harga adalah - 0,160 dengan Sig. t sebesar 0,172 mengindikasikan bahwa kesadaran harga berpengaruh negative secara tidak signifikan terhadap kebingungan konsumen. Koefisien variable tingkat kebutuhan kognisi sebesar 0, 073 dengan Sig. t sebesar 0,569 menunjukan bahwa tingkat kebutuhan kognisi berpengaruh positif secara tidak signifikan terhadap kebingungan konsumen.

Tabel

Hasil Analisis Regresi Linear Berganda Konsumen Perempuan

\begin{tabular}{|c|c|c|c|c|c|}
\hline \multirow[t]{2}{*}{ Model } & \multicolumn{2}{|c|}{ Unstandardized Coefficients } & $\begin{array}{c}\text { Standardized } \\
\text { Coefficients }\end{array}$ & \multirow[t]{2}{*}{$\mathrm{T}$} & \multirow{2}{*}{ Sig. } \\
\hline & $B$ & Std. Error & Beta & & \\
\hline \multirow{4}{*}{$\begin{array}{l}\text { (Constant) } \\
\text { Orientasi Pembelajaran } \\
\text { Kesadaran Harga } \\
\text { Tingkat Kebutuhan } \\
\text { Kognisi }\end{array}$} & 5.672 & 0.803 & & 7.064 & 0.000 \\
\hline & -0.756 & 0.162 & -0.438 & -4.655 & 0.000 \\
\hline & -0.182 & 0.083 & -0.209 & -2.203 & 0.031 \\
\hline & 0.317 & 0.102 & 0.292 & 3.091 & 0.003 \\
\hline \multicolumn{6}{|c|}{ R Square $=0,339$} \\
\hline Adjusted R Square = & \multirow{2}{*}{\multicolumn{5}{|c|}{$=0,313$}} \\
\hline $\mathrm{F}$ & $=12,999$ & & & & \\
\hline Sig & \multicolumn{5}{|c|}{$=0,000$} \\
\hline
\end{tabular}

Berdasarkan hasil analisis pada Tabel dapat disusun persamaan regresi linear sebagai berikut:

$\mathrm{Y}=5.672-0,756 \mathrm{X}_{1}-0,182 \mathrm{X}_{2}+0,317 \mathrm{X}_{3}+\mathrm{e}$

Keterangan:

$\mathrm{Y}=$ Kebingungan Konsumen

$\mathrm{X}_{1} \quad=$ Orientasi Pembelajaran

$\mathrm{X}_{2} \quad=$ Kesadaran Harga

$\mathrm{X}_{3} \quad=$ Tingkat Kebutuhan Kognisi

Nilai $\mathrm{R}^{2}$ sebesar 0,339 dari Tabel berarti bahwa model Consumers Online Tourism mempengaruhi kebingungan konsumen sebesar 33,9 \% sedangkan sisanya sebesar $66,1 \%$ dipengaruhi oleh factor lain. Persamaan regresi yang didapat dari Tabel 5.8 dapat dijelaskan sebagai berikut. Koefisien regresi untuk orientasi pembelajaran pada konsumen perempuan sebesar - 0,756 dengan Sig. t sebesar 0,000 mengindikasikan bahwa orientasi pembelajaran berpengaruh negative dan signifikan terhadap kebingungan konsumen. Koefisien kesadaran harga adalah - 0,182 dengan Sig. t sebesar 0,031 mengindikasikan bahwa kesadaran harga tidak berpengaruh signifikan terhadap kebingungan konsumen. Koefisien variable tingkat 
kebutuhan kognisi sebesar 0,317 dengan Sig. t sebesar 0,006 menunjukan bahwa tingkat kebutuhan kognisi berpengaruh positif dan signifikan terhadap kebingungan konsumen.

Implikasi bagi perusahaan dengan hasil yang didapatkan penelitian ini adalah hendaknya perusahaan memperhatikan target audiens yang dihadapi ketika melakukan komunikasi secara online. Pada konsumen laki-laki, model consumer online tourism confusion hanya 16,3 \% berpengaruh terhadap kebingungan konsumen, sedangkan pada perempuan memiliki pengaruh sebesar 33,9\%. Kebingungan konsumen laki-laki dipengaruhi secara negative oleh orientasi pembelajaran, sehingga perlu diperhatikan tingkat orientasi pembelajaran target audiens laki-laki sebelum melakukan komunikasi online. Kebingungan konsumen perempuan dipengaruhi secara negative oleh orientasi pembelajaran dan dipengaruhi secara positif oleh kebutuhan akan kognisi. Hasil penelitian ini menunjukan bahwa edukasi mengenai penggunaan teknologi dan edukasi mengenai cara mencari informasi produk secara online perlu ditingkatkan perusahaan agar tidak terjadi kebingungan konsumen laki-laki dan perempuan. Selanjutnya pada pada perusahaan yang menargetkan perempuan dengan tingkat kognisi yang tinggi, sebaiknya memperkuat komunikasi secara offline karena memiliki kecenderungan kebingungan dalam mencari informasi secara online. Selain itu, bagi perusahaan yang memiliki target audiens perempuan dengan tingkat kognisi yang tinggi, sebaiknya memberikan informasi secara online dan offline tentang sumber yang dapat dipercaya oleh audience dalam akses informasi secara online.

\section{Kesimpulan dan Saran}

Tujuan penelitian ini adalah untuk melihat pengaruh orientasi pembelajaran, kesadaran akan harga dan kebutuhan akan kognisi terhadap tingkat kebingungan konsumen dalam mencari informasi produk pariwisata. Konsumen yang menjadi subyek penelitian adalah Warga Negara Indonesia di wilayah Badung, Bali yang sedang merencakan liburan yang menggunakan akses internet sebagai sarana pencarian informasi produk pariwisata. Adapun hasil yang didapatkan adalah:

1. Orientasi pembelajaran berpengaruh negative dan signifikan terhadap kebingungan konsumen laki-laki.

2. Kesadaran harga tidak berpengaruh signifikan terhadap kebingungan konsumen lakilaki.

3. Tingkat kebutuhan kognisi tidak berpengaruh signifikan terhadap kebingungan konsumen laki-laki

4. Orientasi pembelajaran berpengaruh negative dan signifikan terhadap kebingungan konsumen perempuan.

5. Kesadaran harga tidak berpengaruh signifikan terhadap kebingungan konsumen perempuan.

6. Tingkat kebutuhan kognisi berpengaruh positif dan signifikan terhadap kebingungan konsumen perempuan.

Hasil penelitian ini dapat digunakan sebagai acuan bagi pemilik usaha dalam memahami perilaku konsumen secara online. Kesadaran harga tidak berpengaruh signifikan terhadap konsumen laki-laki dan perempuan, hal ini berarti perusahaan memiliki peluang untuk memberikan konsumen dengan beragam informasi secara komprehensif secara online berkenaan dengan produk pariwisata yang dikomunikasikan. Orientasi pembelajaran 
berpengaruh negative pada konsumen laki-laki maupun perempuan, sehingga jika target pasar anda adalah tipikal yang memiliki orientasi pembelajaran tinggi, maka akan lebih mudah bagi mereka untuk memutuskan untuk melanjutkan pada proses pembelian dengan informasi yang sangat banyak di internet, penggunaan informasi tentang produk pariwisata yang relevan dan komprehensif sangat disarankan. Tingkat kebutuhan akan kognisi merepresentasikan target pasar yang cukup kompleks dalam pemikiran nya. Perusahaan yang memiliki target pasar perempuan dengan tingkat kebutuhan akan kognisi yang tinggi akan mengalami kecenderungan kebingungan yang tinggi pula, untuk itu upaya penyederhanaan informasi sangat disarankan bagi target pasar dengan tipe ini.

\section{Daftar Pustaka}

Assaker, G. 2010. Insights into tourism demand and tourism behavior/ four papers using multiple perspectives and structural equation modeling (doctoral dissertation). European Journal of Tourism Research, 4, h: 237-241.

Belch, George E. \& Belch, M A. 2003. Advertising and promotion. An integrated marketing communications perspective. Sixth edition. USA: The Mcgraw-Hill Company

Buhalis, D. 1998. Strategic use of information technologies in the tourism industry. Tourism Management, 19 (5), h: 409-421.

Buhalis, D., \& Law, R. 2008. Progress in information technology and tourism management: 20 years on and 10 years after the Internet - The state of eTourism research. Tourism Management, 29 (4), h: 609-623.

DeRue, D. S., \& Wellman, N. 2009. Developing leaders via experience: the role of developmental challenge, learning orientation, and feedback availability. Journal of Applied Psychology, 94, h: 859-875.

DeShon, R. P., \& Gillespie, J. Z. 2005. A motivated action theory account of goal orientation. Journal of Applied Psychology, 90, h:1096-1127.

Cheary, N. 1997. Fashion victim. Marketing Week, 20, h: 36-39

Cohen, A. R., Stotland, E., \& Wolfe, D. M. 1955. An experimental investigation of need for cognition. The Journal of Abnormal and Social Psychology, 51, h: 291-294.

Furnham, A. 1994. A content, correlational and factor analytic study of four tolerance of ambiguity questionnaires. Personality and Individual Differences, 16, h: 403-410.

Frías, D. M., Rodríguez, M. A., \& Castaņeda, J. A. (2008). Internet vs. travel agencies on pre- visit destination image formation: An information processing view. Tourism Management, 29, h:163-179.

Gong, Y., Huang, J.-C., \& Farh, J.-L. 2009. Employee learning orientation, transformational leadership, and employee creativity: The mediating role of employee creative selfefficacy. Academy of Management Journal, 52, h: 765-778. 
Grewal, D., Marmorstein, H. (1994). Market price variation, perceived price variation, and consumers' price search decisions for durable goods. Journal of Consumer Research, 21, h: 453-460.

Gurel, E., Altinay, L., \& Daniele, R. 2010. Tourism students' entrepreneurial intentions. Annals of Tourism Research, 37, h: 646-669.

Jepsen, A. 2006. Information Search in Virtual Communities: Is it Replacing Use of Off-Line Communication? Journal of Marketing Communications, 12 (4), h: 247-261.

Kent, R. J., \& Allen, C. T. 1994. Competitive interference effects in consumer memory for advertising: the role of brand familiarity. The Journal of Marketing, 58, h: 97-105.

Konucs, U., Verhoef, P. C., \& Neslin, S. A. (2008). Multichannel shopper segments and their covariates. Journal of Retailing, 84, h: 398-413

Law, R., Qi, S., \& Buhalis, D. 2010. Progress in tourism management: A review of website evaluation in tourism research. Tourism Management, 31, h: 297-313.

Lichtenstein, D. R., Ridgway, N. M., \& Netemeyer, R. G. 1993. Price perceptions and consumer shopping behavior: a field study. Journal of Marketing Research, 30, h: 234- 245 .

Lu. Allen CC. Dogan Gursoy. 2015 A conceptual model of consumers' online tourism confusion. International Journal of Contemporary Hospitality Management, 27, h: $1320-1342$

Mitchell, V. W., \& Papavassiliou, V. 1997. Exploring consumer confusion in the watch market. Marketing Intelligence \& Planning, 15, h: 164-172.

Mitchell, V. W., \& Papavassiliou, V. 1999. Marketing causes and implications of consumer confusion. Journal of Product \& Brand Management, 8, h: 319-342.

Mitchell, V. W., Walsh, G., \& Yamin, M. 2004. Reviewing and redefining the concept of consumer confusion. Mansucript Manchester School of Management: Manchester.

Montoya-Weiss, M. M., Voss, G. B., \& Grewal, D. 2003. Determinants of online channel use and overall satisfaction with a relational, multichannel service provider. Journal of the Academy of Marketing Science, 31, h: 448-458.

Murray, K. B., \& Schlacter, J. L. 1990. The impact of services versus goods on consumers' assessment of perceived risk and variability. Journal of the Academy of Marketing Science, 181, h: 51-65.

Poiesz, T. B. C., \& Verhallen, T. M. M. 1989. Brand confusion in advertising. International Journal of Advertising, 23, h: 231-244.

Riduwan, 2011, Statistika untuk Penelitian Pendidikan, Sosial, Ekonomi, Komunikasi dan Bisnis. Bandung: Penerbit Alfabeta 
Sirakaya, E., \& Woodside, A. G. 2005. Building and testing theories of decision making by travellers. Tourism management, 26(6), h: 815-832.

Suyana, Utama. 2009. Buku Ajar, Aplikasi Analisis Kuantitatif. Denpasar : Sastra Utama.

Turnbull, P. W., Leek, S., \& Ying, G. 2000. Customer confusion: The mobile phone market. Journal of Marketing Management, 16, h: 143-163.

Walsh, G., \& Hennig-Thurau, T. 2002. Wenn Konsumenten verwirrt sind-Empirische Analyse der Wirkungen eines vernachlässigten Konstruktes. Marketing ZFP, 24, h: 95-109.

Walsh, G., \& Mitchell, V.-W. 2005. Demographic characteristics of consumers who find it difficult to decide. Marketing Intelligence \& Planning, 23, h: 281-295.

Walsh, G., Mitchell, V.-W., \& Frenze, T. 2004. Consumer e-confusion on the Internet. Thexis-Fachzeitschrift für Marketing, 21, h: 17-22.

Walsh, Gianfranco, \& Yamin, M. 2005. Towards a conceptual model of consumer confusion. Advances in Consumer Research, 32, h: 143-50.

Xiang, Z., \& Gretzel, U. 2010. Role of social media in online travel information search. Tourism Management, 31, h: 179-188. 